\title{
Spatial deformation of osteosynthesis systems. Message 1. Criteria of functional reliability
}

\author{
M. S. Shidlovskiy ${ }^{1} \bullet$ M. M. Dyman ${ }^{1} \bullet$ O. P. Zakhovaiko ${ }^{1} \bullet$ T. M. Omelchenko ${ }^{2}$ \\ 1 - Igor Sikorsky Kyiv Polytechnic Institute, Kyiv, Ukraine; \\ 2 - Bogomolets National Medical University, Kyiv, Ukraine
}

Received: 14 February 2020 / Accepted: 24 February 2020

\begin{abstract}
Annotation. Based on experimental studies, an analytical method is proposed for assessing the functional reliability of osteosynthesis systems. As criteria for the rigidity of osteosynthesis systems, displacements and mutual rotations of parts of bone fractures with fixation tools were used. The characteristics of the "bone with a fracture - fixation system", necessary for calculations, determined experimentally from individual loads by compression, bending, and torsion of bone samples with simulated fractures and fixation tools.

The characteristics of the plates for fixation of tibial fractures are determined, the level of allowable loads is calculated according to the combined action of compression, bending and torsion, and the areas of valid loads are determined.

The proposed criteria for functional reliability make it possible, using simple tests and analytical calculations, to determine permissible load levels that do not lead to the occurrence of dangerous movements in the fracture area.

Keywords: osteosynthesis, tibia, functional reliability, stiffness criteria, displacement of fracture parts, linear displacements, mutual rotation angles.
\end{abstract}

\section{Introduction}

During the knitting of bone fractures fixed by means of fixation, in most cases, disposable or reusable, mainly cyclic, loads occur. At the same time, it is impossible to completely eliminate the dangerous displacements of individual points in the fracture area. These displacements can lead to improper reposition of fractures or slow down the process of fusion [1-5].

The practice of using various means of fixation of fractures (OS systems) has shown that one of the main functional indicators of these systems is the mutual linear displacements $(\Lambda)$ of adjacent fracture points and the mutual rotation angles $(\mathrm{G})$ of the fracture parts. Based on many years of research in the field of practical surgery, the established allowable linear displacements (displacement) of fracture points $[\Lambda]=1 \mathrm{~mm}$, and the mutual angles of rotation of the fracture parts $[\mathrm{G}]=3^{\circ}[6,7]$.

Thus, the requirements for deformation indicators of the systems "bone with a fracture - a means of fixation of a fracture", which are determined by the physiological properties and type of fracture, have the form [8]:

$$
\begin{aligned}
& \Lambda_{\max }^{i} \leq[\Lambda] ; \\
& \Gamma_{\max }^{i} \leq[\Gamma],
\end{aligned}
$$

where $i$ is the designation of the fracture points. It can be [9]: $M$ - medial (located in the middle, closer to the longitudinal axis of the human body), $L$ - lateral (located on the side, away from the longitudinal axis), $V$ - ventral (located in front), $D$ - dorsal (located behind) or other fracture points.

\section{Accounting for the mutual displacement of the fracture points}

Displacements and rotation angles in the fracture area are determined by the influence of such forces (Fig. 1, a): $P_{1}$ - force acting along the longitudinal axis of the bone (for the lower extremities it is mainly human gravity); $P_{2}$ - transverse force (muscle strength, limb weight in the supine position of the victim); $P_{3}-$ the force acting on the foot when walking (muscle action during rotational movements of the body during walking, the weight

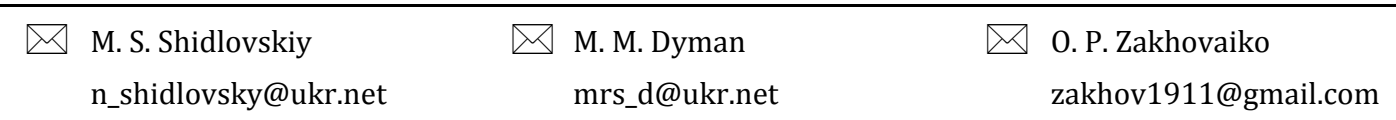


of the foot in the supine position of the victim) and causes torsion of the bones of the limbs. Due to the action of these forces, bending moments and torsion moment arise:

$$
M_{k}=P_{k} \cdot e_{k},
$$

where $e_{k}$ - the distances from the line of action of the corresponding force to the place of fixation of the fracture; $k=1,2,3-$ designation of forces and corresponding moments (Fig. 2).

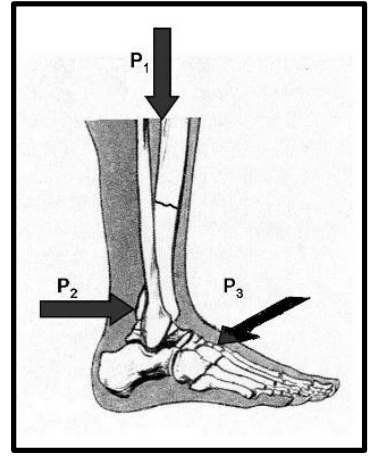

$a$

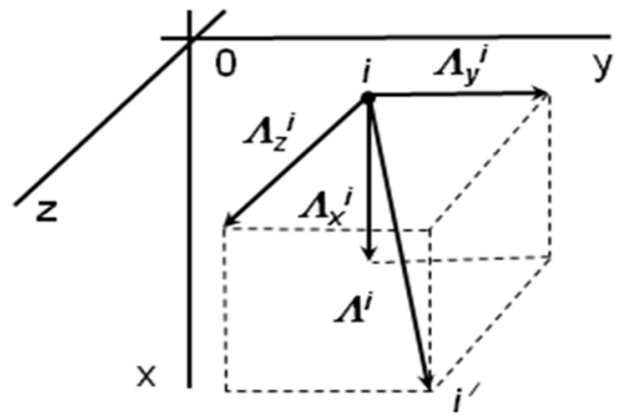

$b$

Fig. 1. Loads acting on the limb $(a)$, directions of the coordinate axes and components of the main displacement vector $\Lambda^{i}(b)$

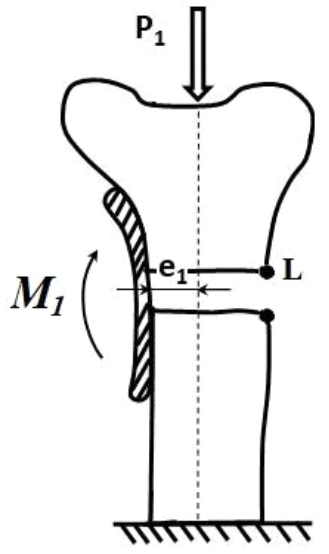

$a$

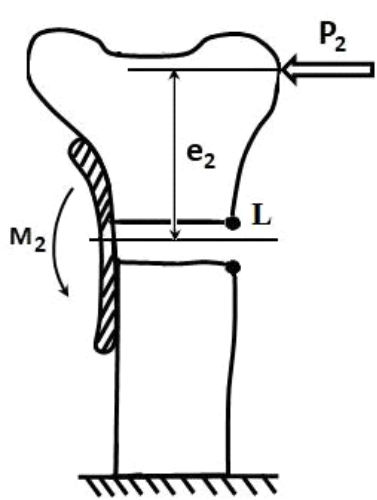

$b$

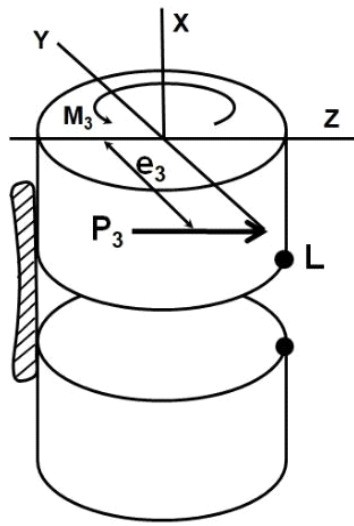

$c$

Fig. 2. Influence of axial $(a)$, transverse $(b)$ forces and torsion moment $(c)$ on the fixation system

We take into account that most OS tools are located on the lateral (external to the center of the body) or medial (internal) side of the bone. In this case, the axis of the longitudinal force P1 passes through the frontal plane (the one that divides the body into the front and back) of the bone. In the future, we consider the case when the line of action of the most dangerous force $P_{2}$ also lies in the front plane. Therefore, the displacement arising from these forces and the corresponding moments must be added algebraically.

Note that the direction (sign) of external forces is not known in advance. Therefore, in what follows we will consider the most dangerous arrangement of the forces $P_{1}, P_{2}$, and $P_{3}$ when the directions of the projections of the movement of all these forces coincide. In this regard, when constructing the criteria of functional reliability, consider that all components of displacements have the same sign.

If the components of the displacement are known (the projections of the total vector $\Lambda$ on the coordinate axis (Fig. 1, $b$ ) at the most dangerous point, then condition (1) can be written as:

$$
\Lambda_{\max }=\left.\sqrt{\left(\Lambda_{x}^{i}\right)^{2}+\left(\Lambda_{y}^{i}\right)^{2}+\left(\Lambda_{z}^{i}\right)^{2}}\right|_{\max } \leq[\Lambda],
$$

where $\Lambda_{j}^{i}\left(\Lambda_{x}^{i}, \Lambda_{y}^{i}, \Lambda_{z}^{i}\right)$ - projections of the full displacement of the point «i» on the axis «j». 
We denote by $\lambda$ the displacements as the ratio of the absolute displacements to the acting forces, and by $\bar{\lambda}$ the displacements as the ratio of the absolute values of the displacements to the acting moments:

$$
\lambda_{j k}^{i}=\frac{\Lambda_{j k}^{i}}{P_{k}} ; \quad \bar{\lambda}_{j k}^{i}=\frac{\Lambda_{j k}^{i}}{M_{k}},
$$

where $\Lambda_{j k}^{i}$-displacement projections of the $i$-th points caused by forces $P_{k}$ on the $j$-th axis.

The reduced displacements are determined experimentally by measuring the displacements under the influence of the corresponding forces and moments, for example, by digital recording using a camera [9, 10, 11].

If the displacements are known, the components of the absolute displacements can be determined for any values of the components of the force vector $P_{k}$ and the corresponding components of the moment vector $M_{k}$. So, the projection of the total displacement $\Lambda^{i}$ on the axis $X$ is determined as follows:

$$
\Lambda_{x}^{i}=\lambda_{x 1}^{i} \cdot P_{1}+\lambda_{x 2}^{i} \cdot P_{2}+\lambda_{x 3}^{i} \cdot P_{3}+\bar{\lambda}_{x 1}^{i} \cdot M_{1}+\bar{\lambda}_{x 2}^{i} \cdot M_{2}+\bar{\lambda}_{x 3}^{i} \cdot M_{3}
$$

The projections of the displacement $\Lambda^{i}$ on the $Y$ and $Z$ axes are determined similarly. In general terms, we have:

$$
\Lambda_{j}^{i}=\sum_{i=1}^{3} P_{k}\left(\lambda_{j k}^{i}+\bar{\lambda}_{j k}^{i} \cdot e_{k}\right) .
$$

The stiffness condition (3) using, as a criterion, the maximum linear mutual displacement in compressed form is written as follows:

$$
\Lambda_{\max }=\sqrt{\sum_{j=1}^{3}\left[\sum_{k=1}^{3} P_{k}\left(\lambda_{j k}^{i}+\bar{\lambda}_{j k}^{i} \cdot e_{k}\right)\right]^{2}} \leq[\Lambda]
$$

\section{Accounting for the angles of mutual rotation of the parts of the fracture}

The angle of rotation of the line connecting two opposite fracture points $M$ and $L$.

$$
\Gamma=\arccos \left(1-\frac{\left|L^{\prime} L_{2}\right|^{2}}{2 S_{M L}^{2}}\right),
$$

where $S_{M L}=M_{1} L_{1}=M_{2} L_{2}=M_{2} L^{\prime}$ - the distance between points $M$ and $L$ in different positions (Fig. 3); $M_{1}, L_{1}$ - the position of two opposite fracture points to the load; $M_{2}, L_{2}$ - position of two opposite fracture points after loading; $\Lambda_{X}^{M}, \Lambda_{Y}^{M}, \Lambda_{Z}^{M}, \Lambda_{X}^{L}, \Lambda_{Y}^{L}, \Lambda_{Z}^{L}$ - projections of the displacement of points $M$ and $L$ on the axis $X, Y, Z ; L^{\prime}-$ the position of point $L$ after application of the load without taking into account the rotation of the fracture (parallel displacement of the segment $\left.M_{1} L_{1}\right) ; L^{\prime} L_{2}$ - the displacement of the point $L$ due to only the mutual rotation of the fracture parts.

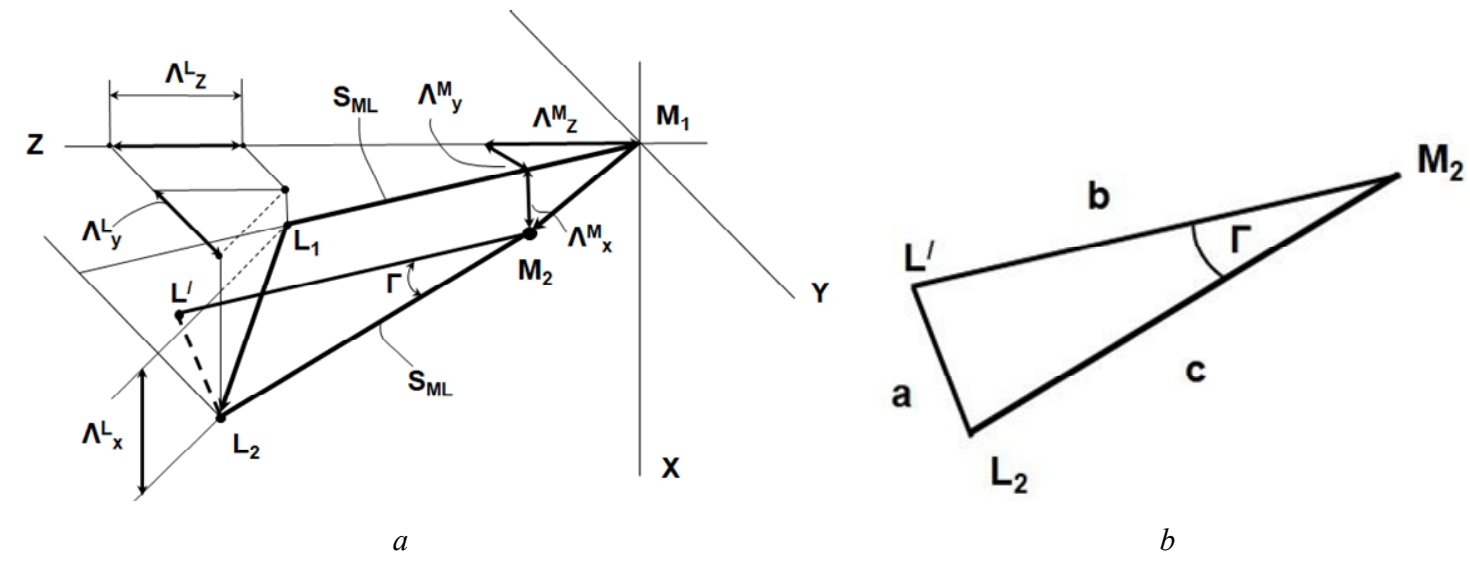

Fig. 3. Detailed ( $a$ ) and simplified $(b)$ scheme of movement of fracture points and angles of rotation of fracture parts 
Choosing the maximum mutual angle of rotation of the fracture parts as the rigidity criterion and taking into account the relation (5), condition (2) is obtained in the following form:

$$
\Gamma_{\max }=\left.\arccos \left\{1-\frac{1}{2 S_{M L}^{2}} \cdot \sum_{j=1}^{3}\left[\sum_{k=1}^{3} P_{k}\left(\left(\lambda_{j k}^{L}-\lambda_{j k}^{M}\right)+\left(\bar{\lambda}_{j k}^{L}-\bar{\lambda}_{j k}^{M}\right) \cdot e_{k}\right)\right]^{2}\right\}\right|_{\max } \leq[\Gamma],
$$

\section{Accounting for cyclic loads}

The process of treating victims is accompanied by exposure to limbs cyclically acting loads (walking, exercise). In this case, the mutual displacements of the fracture points can significantly increase, and the conditions of stiffness (4) and (6) must take into account the deformations (displacements) that accumulate in the OS system during the application of cyclic loads:

$$
\begin{aligned}
\Lambda_{\max }(N)= & \left\{\sum_{j=1}^{3}\left[\sum_{k=1}^{3} P_{k}\left(\left(\lambda_{j k(0)}^{i}-\lambda_{j k(N)}^{i}\right)+\left(\bar{\lambda}_{j k(0)}^{i}-\bar{\lambda}_{j k(N)}^{i}\right) \cdot e_{k}\right)\right]^{2}\right\}^{1 / 2} \leq[\Lambda] ; \\
\Gamma_{\max }(N)= & \arccos \left\{1-\frac{1}{2 \cdot S_{M L}^{2}} \cdot \sum_{j=1}^{3}\left[\sum _ { k = 1 } ^ { 3 } P _ { k } \left(\left(\lambda_{j k(0)}^{L}+\lambda_{j k(N)}^{L}-\lambda_{j k(0)}^{M}-\lambda_{j k(N)}^{M}\right)+\right.\right.\right. \\
& \left.\left.\left.+\left(\bar{\lambda}_{j k(0)}^{L}+\bar{\lambda}_{j k(N)}^{L}-\bar{\lambda}_{j k(0)}^{M}-\bar{\lambda}_{j k(N)}^{M}\right) \cdot e_{k}\right)\right]^{2}\right\}\left.\right|_{\max } \leq[\Gamma] .
\end{aligned}
$$

In (7) and (8) it was taken into account that the components of the point displacement consist of instantly elastic displacement $\Lambda_{j k(0)}^{i}$ and displacement $\Lambda_{j k(N)}^{i}$ that occurred during the action of $N$ loading cycles (Fig. 6)

$$
\Lambda_{j k}^{i}=\Lambda_{j k(0)}^{i}+\Lambda_{j k(N)}^{i}
$$

This ratio can be expressed through the reduced displacements which are related to the action of forces $\left(\lambda_{j k}^{i}\right)$ and moments $\left(\bar{\lambda}_{j k}^{i}\right)$ :

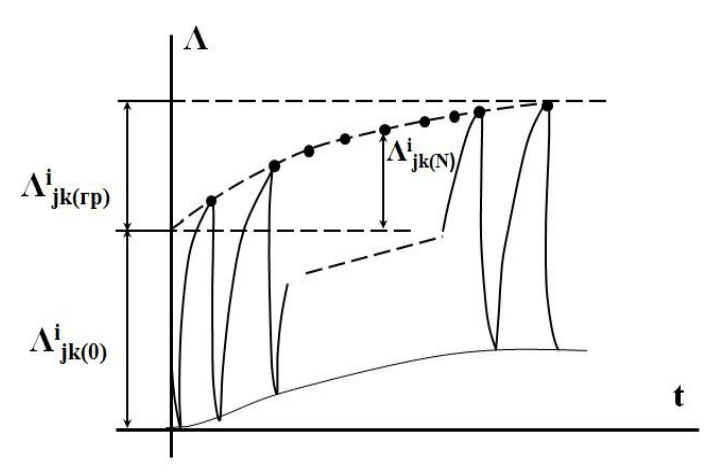

Fig. 4. Scheme of development of displacements of adjacent points and accepted notations

$$
\lambda_{j k}^{i}=\lambda_{j k(0)}^{i}+\lambda_{j k(N)}^{i} ; \bar{\lambda}_{j k}^{i}=\bar{\lambda}_{j k(0)}^{i}+\bar{\lambda}_{j k(N)}^{i}
$$

Index 0 means instant-elastic component, index $N-$ accumulated displacements:

$$
\begin{aligned}
\lambda_{j k(0)}^{i}=\frac{\Lambda_{j k(0)}^{i}}{P_{k}} ; & \lambda_{j k(N)}^{i}=\frac{\Lambda_{j k(N)}^{i}}{P_{k}} ; \quad \bar{\lambda}_{j k(0)}^{i}=\frac{\Lambda_{j k(0)}^{i}}{M_{k}} ; \\
\bar{\lambda}_{j k(N)}^{i} & =\frac{\Lambda_{j k(N)}^{i}}{M_{k}} .
\end{aligned}
$$

From a practical point of view, the greatest interest is the displacement of the points of fracture, which accumulate when exposed to a sufficiently significant number of load cycles. In this case, conditions (7), (8) show displacements that occur on the $N$-th cycle, it is expedient to replace them with limiting ones (with the maximum number of cycles):

$$
\begin{gathered}
\Lambda_{\max }=\left.\left\{\sum_{j=1}^{3}\left[\sum_{k=1}^{3} \mathrm{P}_{\mathrm{k}} \cdot k_{j k}^{i}\left(\lambda_{\mathrm{jk}(0)}^{\mathrm{i}}+\bar{\lambda}_{\mathrm{jk}(0)}^{\mathrm{i}} \cdot \mathrm{e}_{\mathrm{k}}\right)\right]\right\}^{1 / 2}\right|_{\max } \leq[\Lambda] ; \\
\Gamma_{\max }=\arccos \left\{1-\frac{1}{2 \cdot S_{M L}^{2}} \cdot \sum_{j=1}^{3}\left[\sum _ { k = 1 } ^ { 3 } P _ { k } \left(k_{j k}^{L}\left(\lambda_{j k(0)}^{L}+\bar{\lambda}_{j k(0)}^{L} \cdot e_{k}\right)-\right.\right.\right. \\
\left.\left.\left.-k_{j k}^{M}\left(\lambda_{j k(0)}^{M}+\bar{\lambda}_{j k(0)}^{M} \cdot e_{k}\right)\right)\right]^{2}\right\} \leq[\Gamma],
\end{gathered}
$$


where

$$
k_{j k}^{i}=1+\frac{\Lambda_{j k(2 p)}^{i}}{\Lambda_{j k(0)}^{i}}
$$

is the coefficient of influence of cyclic creep, which shows an increase in the total displacement occurring at a significant number of cycles compared to the displacement under a single load.

\section{Analytical description of cyclic creep curves}

Previous experiments have shown that the curve that connects the upper points of the cyclic creep diagram (dashed in Fig. 4) it is possible to approximate with a sufficient degree of accuracy the sum of exponential functions. The number of members of this sum is sufficient to limit by three so that the error of approximation does not exceed the instrumental error. This is, in fact, the use of a generalized Kelvin-Voigt model by formally replacing the period of the force's application by the number of load cycles.

Imagine fracture displacements under the action of long cyclic loads as follows:

$$
\Lambda_{j k}^{i}(N)=\Lambda_{j k(0)}^{i}+\sum_{m=1}^{n} \Lambda_{j k(m)}^{i}\left[1-\exp \left(-\frac{N}{N_{m}^{i}}\right)\right],
$$

where $\Lambda_{j k(0)}^{i}$ - displacements, can be determined under single loads; $\Lambda_{j k(m)}^{i}, N_{m}^{i}$ - coefficients that can be determined from cyclic creep curves; $N$ - number of load cycles; $m$ is the serial number of the exponent; $n$ is the total number of exponents.

Dividing both parts (12) by $P_{k}$, we obtain for the reduced displacement $\lambda_{j k(N)}^{i}$ :

$$
\lambda_{j k}^{i}(N)=\lambda_{j k(0)}^{i}+\sum_{m=1}^{n} \lambda_{j k(m)}^{i}\left[1-\exp \left(-\frac{N}{N_{m}^{i}}\right)\right] .
$$

Similarly for the reduced displacement $\bar{\lambda}_{j k}^{i}(N)$ :

$$
\bar{\lambda}_{j k}^{i}(N)=\bar{\lambda}_{j k(0)}^{i}+\sum_{m=1}^{n} \bar{\lambda}_{j k(m)}^{i}\left[1-\exp \left(-\frac{N}{\bar{N}_{m}^{i}}\right)\right] .
$$

\section{Generalized forms of conditions of functional reliability}

Taking into account (13) and (14), the stiffness conditions (7) and (8) at repeated cyclic loads will have the following form:

$$
\begin{gathered}
\Lambda_{\max }(N)=\left\{\sum _ { j = 1 } ^ { 3 } \left[\sum _ { k = 1 } ^ { 3 } P _ { k } \cdot \left(\left(\lambda_{j k(0)}^{i}+\sum_{m=1}^{n} \lambda_{j k(m)}^{i}\left[1-\exp \left(-N / N_{m}^{i}\right)\right]\right)+\right.\right.\right. \\
\left.\left.\left.+\left(\bar{\lambda}_{j k(0)}^{i}+\sum_{m=1}^{n} \bar{\lambda}_{j k(m)}^{i}\left[1-\exp \left(-N / \bar{N}_{m}^{i}\right)\right]\right) \cdot e_{k}\right)\right]^{2}\right\}\left.^{1 / 2}\right|_{\max } \leq[\Lambda] ; \\
\Gamma_{\max }(N)=\arccos \left\{1-\frac{1}{2 \cdot S_{M L}^{2}} \cdot \sum_{j=1}^{3}\left[\sum _ { k = 1 } ^ { 3 } P _ { k } \cdot \left(\left(\lambda_{j k(0)}^{L}+\sum_{m=1}^{n} \lambda_{j k(m)}^{L} \cdot\left[1-\exp \left(-N / N_{m}^{L}\right)\right]-\right.\right.\right.\right. \\
\left.-\lambda_{j k(0)}^{M}-\sum_{m=1}^{n} \lambda_{j k(m)}^{M} \cdot\left[1-\exp \left(-N / N_{m}^{M}\right)\right]\right)+\left(\bar{\lambda}_{j k(0)}^{L}+\sum_{m=1}^{n} \bar{\lambda}_{j k(m)}^{L}\left[1-\exp \left(-N / \bar{N}_{m}^{L}\right)\right]-\right. \\
\left.\left.\left.\left.-\bar{\lambda}_{j k(0)}^{M}-\sum_{m=1}^{n} \bar{\lambda}_{j k(m)}^{M}\left[1-\exp \left(-N / \bar{N}_{m}^{M}\right)\right]\right)\right)\right]^{2}\right\}\left.\right|_{\max } \leq[\Gamma] .
\end{gathered}
$$




\section{Determination of the allowable loads at fractures of tibia bone, fixed with plates}

As an example, consider the application of the above criteria to estimate the allowable loads of the system "tibia with fracture - fixing plate" $[8,12,13]$. The following points of fracture were considered: point $M$ (medial, point near the attachment of the plates) and point $L$ (lateral, the point furthest from the plates). We assume that the external forces are applied in such a way that the directions of the projections of the displacement vectors of the point $L$, which arise due to individual forces and moments of forces, coincide (the most dangerous case).

According to formula (4), in order to accurately evaluate the functional reliability of the fracture fixation and to determine the allowable loads, it is necessary to know nine values of the reduced displacements $\lambda_{j k}^{i}$ and nine values of $\bar{\lambda}_{j k}^{i}$. Obviously, identifying all the components, even using the digital method of recording movements [9], is quite difficult. However, it turned out that the number of displacements that influence the results of calculations can be significantly smaller.

The above displacements were determined from the results of experiments for angled medial plates with angular stability (hereinafter 2M), medial blocked plates (3M), and $X$-shaped medial blocked plates for open correction osteotomy (4M).

Tibial bones with simulated fractures fixed by these plates have been tested for compression, bending and torsion by the method $[9,14]$. In table 1 shows the distances from the points of application of loads to the locking plates.

The location of the point of application of loads to the locking plate (see Fig. 2)

Table 1

\begin{tabular}{|c|c|c|c|}
\hline Type of plates & $e_{1}$ & $e_{2}$ & $e_{3}$ \\
\hline $2 \mathrm{M}$ & 11.0 & 21.5 & 59.5 \\
\hline $3 \mathrm{M}$ & 17.5 & 20.6 & 56.9 \\
\hline $4 \mathrm{M}$ & 21.1 & 35.8 & 49.8 \\
\hline
\end{tabular}

The most dangerous area is the area of fracture in which, under the action of loads, maximum mutual displacements of adjacent points occur. It is obvious (and this is confirmed experimentally) that in most cases maximum displacements will occur at the point of fracture farthest from the fixation means (plate or rod apparatus of external fixation). Therefore, in our opinion, as the point $\mathrm{i}$ in the calculations of maximum displacements, we need to take the point itself from the clamp (point $L$ in Fig. 2).

Analyzing the experimental material $[12,14]$ we can conclude that the main displacement vector $\Lambda$ is determined mainly by the components $\Lambda_{X 1}^{i}, \Lambda_{X 2}^{i}, \Lambda_{Z 1}^{i}, \Lambda_{Z 2}^{i}$, and $\Lambda_{Y 3}^{i}$.

The first four components are the longitudinal (along the $X$-axis) and transverse (along the $Z$-axis) displacements by forces $P_{1}$ and $P_{2}$. The fifth component - is the displacement in the plane perpendicular to the longitudinal axis of the bone due to the moment of rotation $M_{3}$.

The results of calculations of the reduced displacements, which are included in formulas (4) and (6), are given in Table 2. The other components of the displacement of the breakpoints are close to zero and are within the measurement error.

Table 2

The reduced displacements of the point farthest from the fixing point by the plate $L$ and closest to the plate $M$

\begin{tabular}{|c|c|c|c|c|c|c|}
\hline \multirow{2}{*}{ Plate } & $\lambda_{x 1}^{L}, \lambda_{x 1}^{M}$ & $\lambda_{z 2}^{L}, \lambda_{z 2}^{M}$ & $\bar{\lambda}_{x 1}^{L}$ & $\bar{\lambda}_{x 2}^{L}$ & $\bar{\lambda}_{y 3}^{L}$ & $\bar{\lambda}_{z 1}^{L}, \bar{\lambda}_{z 2}^{L}, \bar{\lambda}_{z 1}^{M}, \bar{\lambda}_{z 2}^{M}$ \\
\cline { 2 - 7 } & \multicolumn{2}{|c|}{$\times 10^{3}, \mathrm{~mm} / N$} & \multicolumn{4}{|c|}{$\times 10^{3}, \mathrm{~mm} /(N \cdot \mathrm{mm})$} \\
\hline $2 \mathrm{M}$ & 3.03 & 2.13 & 0.458 & 0.460 & 0.702 & 0.105 \\
\hline $3 \mathrm{M}$ & 4.75 & 0.64 & 0.429 & 0.427 & 1.213 & 0.134 \\
\hline $4 \mathrm{M}$ & 0.80 & 2.77 & 0.193 & 0.189 & 0.319 & 0.023 \\
\hline
\end{tabular}

Taking into account only those non-zero displacements, the conditions of functional reliability (4), (6) under simplified loads significantly simplify:

$$
\begin{aligned}
\Lambda_{\max }= & \left\{\left[P_{1}\left(\lambda_{x 1}^{L}+\bar{\lambda}_{x 1}^{L} \cdot e_{1}\right)+P_{2} \cdot \bar{\lambda}_{x 2}^{L} \cdot e_{2}\right]^{2}+\left[P_{3}\left(\bar{\lambda}_{y 3}^{L} \cdot e_{3}\right)\right]^{2}+\right. \\
& \left.+\left[P_{1}\left(\bar{\lambda}_{z 1}^{L} \cdot e_{1}\right)+P_{2} \cdot\left(\lambda_{z 2}^{L}+\bar{\lambda}_{z 2}^{L} \cdot e_{2}\right)\right]^{2}\right\}^{1 / 2} \mid \leq[\Lambda]
\end{aligned}
$$




$$
\Gamma_{\max }=\left.\arccos \left\{1-\frac{1}{2 S_{M L}^{2}}\left[\left(P_{1} \cdot \bar{\lambda}_{x 1}^{L} \cdot e_{1}+P_{2} \cdot \bar{\lambda}_{x 2}^{L} \cdot e_{2}\right)^{2}+\left(P_{3} \cdot \bar{\lambda}_{y 3}^{L} \cdot e_{3}\right)^{2}\right]\right\}\right|_{\max } \leq[\Gamma]
$$

Using the criterion of maximum linear displacement recorded in the form (17) and the value of the reduced displacements, are given in Table 2 , the values of the allowable loads $\left[P_{1}\right],\left[P_{2}\right]$ and $\left[P_{3}\right]$ were calculated with their simultaneous action. The results of the calculations are shown in Table 3 . It is permissible for the reciprocal movement of the breakpoints to be taken $[\Lambda]=1 \mathrm{~mm}$.

Allowable loads $\left[P_{1}\right],\left[P_{2}\right]$ and $\left[P_{3}\right]$ that do not lead to the mutual displacement of fracture points

Table 3 by more than $1 \mathrm{~mm}$ when fixing the fracture by different types of plates

\begin{tabular}{|c|c|c|c|c|c|c|c|c|}
\hline \multicolumn{3}{|c|}{ Plate 2M } & \multicolumn{3}{|c|}{ Plate $3 \mathrm{M}$} & \multicolumn{3}{|c|}{ Plate 4M } \\
\hline$\left[P_{1}\right], N$ & {$\left[P_{2}\right], N$} & {$\left[P_{3}\right], N$} & {$\left[P_{1}\right], N$} & {$\left[P_{2}\right], N$} & {$\left[P_{3}\right], N$} & {$\left[P_{1}\right], N$} & {$\left[P_{2}\right], N$} & {$\left[P_{3}\right], N$} \\
\hline \multirow{4}{*}{0} & 0 & 9.50 & \multirow{4}{*}{0} & 0 & 5.49 & \multirow{4}{*}{0} & 0 & 20.89 \\
\hline & 40.0 & 8.56 & & 40.0 & 5.09 & & 40.0 & 19.90 \\
\hline & 80.0 & 4.75 & & 80.0 & 3.61 & & 100.0 & 13.44 \\
\hline & 92.4 & 0 & & 105.9 & 0 & & 130.2 & 0 \\
\hline \multirow{4}{*}{60} & 0 & 8.28 & \multirow{4}{*}{40} & 0 & 4.76 & \multirow{4}{*}{60} & 0 & 19.98 \\
\hline & 20.0 & 6.79 & & 20.0 & 4.00 & & 30.0 & 17.94 \\
\hline & 40.0 & 3.88 & & 40.0 & 2.68 & & 60.0 & 14.07 \\
\hline & 48.1 & 0 & & 53.5 & 0 & & 94.2 & 0 \\
\hline \multirow{4}{*}{80} & 0 & 7.20 & \multirow{4}{*}{60} & 0 & 3.64 & \multirow{4}{*}{100} & 0 & 18.23 \\
\hline & 10.0 & 6.21 & & 10.0 & 2.97 & & 20.0 & 16.16 \\
\hline & 20.0 & 4.81 & & 20.0 & 1.95 & & 40.0 & 13.03 \\
\hline & 33.0 & 0 & & 27.0 & 0 & & 69.1 & 0 \\
\hline 122.6 & 0 & 0 & 80.1 & 0 & 0 & 203.7 & 0 & 0 \\
\hline
\end{tabular}

Note: Calculations of allowable loads are made provided that the force $P_{3}$ acts at a distance of $e_{3}=150 \mathrm{~mm}$ from the longitudinal axis of the tibia bone (lateral loading on the distal region of the 1st metatarsal bone).

The allowable loads calculated by condition (18) using the allowable angle of mutual rotation of the fracture parts at $[\mathrm{G}]=3^{\circ}$ had significantly larger values. Because the values of loads (Table 3 ) calculated through the allowable linear displacements under condition (17) were selected as valid ones.

For clarity, the data in table 3 is presented in the form of three-dimensional diagrams (limit regions) that limit the areas of allowable loads. Any point under each of the surfaces corresponds to three values of loads $P_{1}, P_{2}$, and $P_{3}$, the joint action of which leads to the occurrence of displacements and angles of rotation of fracture parts exceeding allowable: $[\Lambda]<1 \mathrm{~mm}$ and $[\mathrm{G}]<3^{\circ}$.

If the point belongs to the surface, then this combination of $P_{1}, P_{2}$, and $P_{3}$ causes a displacement of $[\Lambda]=1 \mathrm{~mm}$. In the case where the point is beyond the limiting surface, such a combination of loads is dangerous, with the displacement of the fracture point $\Lambda>1 \mathrm{~mm}$ away from the plate.
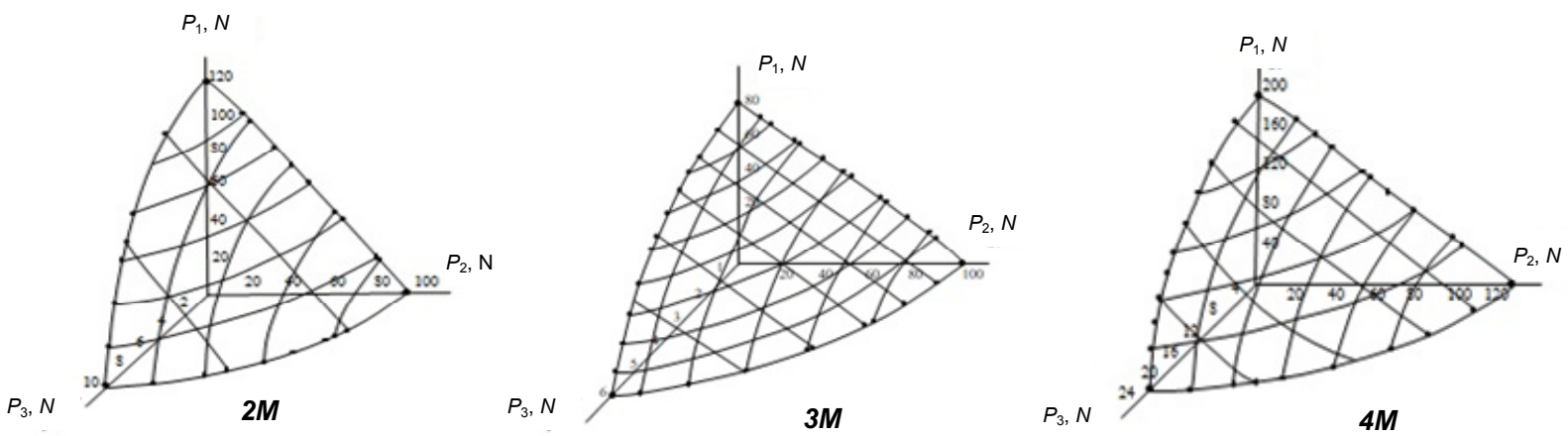

Fig. 4. Areas of allowable loads $\left[P_{1}\right],\left[P_{2}\right]$ and $\left[P_{3}\right]$ that do not lead to physiologically dangerous displacements greater than $[\Lambda]=1 \mathrm{~mm}$ 
It should be noted that the reduced displacements (see Table 2) were determined experimentally on full-scale bone specimens with simulated diastase fractures not filled with bone regenerate. This fracture state corresponds only to the initial stages of fusion, when the regenerate is absent or the mechanical properties do not affect the deformation (displacement) of the fracture points under the influence of physiological loads.

Therefore, the values of allowable loads (see Table 3), calculated using these reduced displacements, also correspond only to the initial condition of the bone regenerate. To determine the allowable loads for later stages of fracture fusion, it is necessary to know the kinetics of changes in the deformation properties of bone tissue in the fracture region during its regeneration.

\section{Conclusions}

1. The criterion ratios obtained for calculating load levels that do not cause unacceptable displacements and mutual rotations of fracture parts. The coefficients required for the calculations (displacements are given) are determined by simple tests at separate loads by compressing, bending, and torsion of bone samples with simulated fractures and fixation means.

2. Using displacement data obtained for simple types of loads (compression, bending, torsion), displacements for three types of plates for fixing tibial fractures are calculated.

3. For set reduced displacements, the levels of allowable loads at the combined action of compression, bending and torsion are calculated, and the areas of allowable loads application are determined. Under the acting of these allowable loads, linear and angular displacements in fractures will be within physiologically justified values (mutual displacement within $1 \mathrm{~mm}$, rotation angle within $3^{\circ}$ ).

\section{References}

1. Ахмедов Б.А. Остеосинтез пластинами с угловой стабильностью винтов в лечении огнестрельных переломов длинных костей конечностей / Б.А. Ахметов, Р.М. Тихилов, А.Р. Атаев // Травматология и ортопедия России. -2007. - Т. 44, №2. - С. 17-23.

2. Билинский П.И. Теоретический анализ биомеханических аспектов остеосинтеза при косом переломе большеберцовой кости контактными и малоконтактными пластинами (сообщение второе) / П.И. Билинский, В.П. Чаплинский, В.А. Андрейчин // Травма. - 2013. - Т. 14, №4. - С. 51-56.

3. Аналіз стану травматолого-ортопедичної допомоги населенню України в $2004-2005$ рр.: Довід. / Г.В. Гайко, М.О. Корж, А.В. Калашніков [та ін.] - К.: Воля. - 2007. - 132 с.

4. Адрианов М.В. Опыт применения имплантируемых стержневых аппаратов системы А.И. Блискунова / М.В. Адрианов, В.Н. Кокурников, Эль Самад Абдул Мохамед // Новое в ортопедии, травматологии и комбустиологии. Ялта, 1997. - С. 26-27.

5. Бейдик О.В. Метод стержневого чрескостного остеосинтеза в лечении диафизарных переломов костей голени / О.В. Бейдик, К.К. Левченко, Ю.В. Трошкин // Гений ортопедии. - 2009. - №4. - С. 114-120.

6. Tonin M.S. (2009), Biomechanical systems of osteosynthesis in the treatment of clavicle fractures : Author's thesis [Biomehanicheskie sistemyi osteosinteza pri lechenii perelomov klyuchitsyi : avtoref. dis. kand. phys-mat. nauk], Saratov, Russian. -22 p.

7. Гуцуляк В.І., Сулима В.С., Шібель І.В. Біомеханічне обгрунтування клінічного застосування універсального апарата 3 адаптацією форми опор до анатомічної конфігурації сегмента кінцівки // Журнал Травма. - № 6 (15), 2014. - С. 65 71.

8. Шидловський М.С., Заховайко О.П., Димань М.М. Деформаційні критерії функціональної надійності систем остеосинтезу // В кн.: Матеріали міжнародної науково - технічної конференції "Прогресивна техніка, технологія та інженерна освіта" - 19 - 22 червня 2018 р., м. Київ, Україна, - С. 55-58.

9. Експериментальні дослідження засобів остеосинтезу. Кол. авторів / За ред. Шидловського М.С., Лакши А.М., - К.: Ленвіт, 2017. - 277 с.

10. Шидловський М.С., Заховайко О.П., Димань М.М. Патент на корисну модель № 117085 Спосіб визначення зміщення уламків кісток в місцях переломів Зареєстровано 12.06.2017 р., Бюл. № 11, 2017.

11. Шидловський М.С., Заховайко О.П., Димань М.М. Порівняльні показники надійності систем остеосинтезу // Біомедична інженерія, № 4, 2017, С. 96-100.

12. Бур'янов О.А., Шидловський М.С., Омельченко Т.М., Димань М.М., Мусієнко О.С. Деформаційні характеристики систем фіксації, що застосовуються при переломах та корекційних остеотоміях дистального відділу великогомілкової кістки // Літопис травматології та ортопедії. - № 1-2(35-36), 2017. - С. 129-133, http://nbuv.gov.ua/UJRN/Lto_2017_1-2_29

13. Димань М.М. Дослідження біомеханічних характеристик засобів фіксації переломів кісток кінцівок // В кн.: Матеріали міжнародної науково - технічної конференції "Прогресивна техніка, технологія та інженерна освіта" - 19 22 червня 2018 р., м. Київ, Україна, - С. 48-51.

14. Шидловський М.С., Димань М.М., Омельченко Т.М. Деформаційні характеристики систем фіксації переломів великогомілкових кісток // В кн.: Матеріали XVIII міжнародної науково - технічної конференції "Прогресивна техніка, технологія та інженерна освіта" - 29 червня - 1 липня 2017 р., м. Київ, Україна, - С. 64-66. 


\title{
Пространственное деформирование систем остеоситеза. Сообщение 1. Критерии функциональной надежности
}

\author{
Н. С. Шидловский, М. М. Дымань, А. П. Заховайко, Т. Н. Омельченко
}

Аннотация. На основе экспериментальных исследований предложено аналитический способ оценки функциональной надежности систем остеосинтеза. Как критерии жесткости систем остеосинтеза использовано перемещения и взаимные повороты частей переломов костей со средствами фиксации. Характеристики системы "кость с переломом средство фиксации”, необходимые для расчетов, определенные экспериментально отдельных нагрузок сжатия, изгиба и кручения образиов костей с моделированными переломами и системами фиксачии.

Определены характеристики пластин для фиксаиии переломов большеберцовой костей, рассчитано уровни допустимых нагрузок при совместных действиях сжатия, изгиба и кручение, определены области действия допустимых нагрузок.

Предложенные критерии функииональной надежности дают возможность с помощью простых испьтаний $u$ аналитических расчетов определять допустимые уровни нагрузок, которые не приводят к возникновению опасных перемещений в области перелома.

Ключевые слова: остеосинтез, большебериовая кость, функииональная надежность, критерии жесткости, смещения частей перелома, линейные перемещения, взаимные угль поворота.

\section{Просторове деформування систем остеосинтезу. Повідомлення 1. Критерії функціональної надійності}

\author{
М. С. Шидловський, М. М. Димань, О. П. Заховайко, Т. М. Омельченко
}

Анотація. На основі експериментальних досліджень запропоновано аналітичний спосіб оцінки функиіональної надійності систем остеосинтезу. Як критерії жорсткості систем остеосинтезу використано переміщення та взаємні повороти частин переломів кісток з засобами фіксаиії. Характеристики системи "кістка з переломом - засіб фіксацї", необхідні для розрахунків, визначені експериментально за окремих навантажень стиском, згином та крученням зразків кісток з модельованими переломами та засобами фіксації.

Визначені характеристики пластин для фіксачії переломів великогомілкових кісток, розраховано рівні допустимих навантажень за сумісної дії стиску, згину та кручення і визначені області дї̈ допустимих навантажень.

Запропоновані критерії функиіональної надійності дають можливість за допомогою простих випробувань та аналітичних розрахунків визначати допустимі рівні навантажень, які не призводять до виникнення небезпечних переміщень в області перелому.

Ключові слова: остеосинтез, великогомілкова кістка, функиіональна надійність, критерії жорсткості, зміщення частин перелому, лінійні переміщення, взаємні кути повороту.

\section{References}

1. Ahmedov, B.A., Tihilov, R.M. and Ataev, A.R. (2007), Osteosintez plastinami s uglovoy stabilnostyu vintov v lechenii ognestrelnyih perelomov dlinnyih kostey konechnostey, Travmatologiva i ortopediya Rossii, vol. 44, no. 2, pp. 17-23.

2. Bilinskiy, P.I., Chaplinskiy, V.P. and Andreychin, V.A. (2013), Teoreticheskiy analiz biomehanicheskih aspektov osteosinteza pri kosom perelome bolshebertsovoy kosti kontaktnyimi i malokontaktnyimi plastinami (soobschenie vtoroe),Travma, vol. 14, no. 4, pp. 51-56.

3. Gayko, G.V., Korzh, M.O., Kalashnikov, A.V. ta In. (2007), Analiz stanu travmatologo-ortopedichnoyi dopomogi naselennyu UkraYini v $2004-2005$ rr., Dovid, K. Volya.

4. Adrianov, M.V., Kokurnikov, V.N. and El Samad Abdul Mohamed, (1997), Opyit primeneniya implantiruemyih sterzhnevyih apparatov sistemyi A.I. Bliskunova, Novoe v ortopedii, travmatologii i kombustiologii, Yalta, pp. 26-27.

5. Beydik, O.V., Levchenko, K.K. and Troshkin, Yu.V. (2009), Metod sterzhnevogo chreskostnogo osteosinteza v lechenii diafizarnyih perelomov kostey goleni, Geniy ortopedii, no. 4. pp. 114-120.

6. Tonin, M.S. (2009), Biomechanical systems of osteosynthesis in the treatment of clavicle fractures: Author's thesis [Biomehanicheskie sistemyi osteosinteza pri lechenii perelomov klyuchitsyi : avtoref. dis. kand. phys-mat. nauk], Saratov, Russian.

7. Gutsulyak, V.I., Sulima, V.S. and Shibel, I.V. (2014), Biomehanichne obgruntuvannya klinichnogo zastosuvannya universalnogo aparata z adaptatsieyu formi opor do anatomichnoyi konflguratsiyi segmenta kintsivki, Zhurnal Travma, vol. 15, no. 6, pp. 65-71.

8. Shidlovskiy, M.S., Zahovayko, O.P.and Diman, M.M. (2018), Deformatsiyni kriteriyi funktsionalnoyi nadiynosti sistem osteosintezu, V kn.: Materiali mizhnarodnoyi naukovo - tehnichnoyi konferentsiyi "Progresivna tehnika, tehnologiya ta inzhenerna osvita", 19 - 22 chervnya, Kyiv, Ukraina, pp. 55-58.

9. Shidlovskogo, M.S. and Lakshi, A.M., Za red. (2017), Eksperimentalni doslidzhennya zasobiv osteosintezu, Kol. Avtoriv, K.: Lenvit,

10. Shidlovskiy, M.S., Zahovayko, O.P. and Diman, M.M. (2017), Patent na korisnu model \# 117085 SposIb viznachennya zmischennya ulamkiv kistok v mistsyah perelomiv. 12.06.2017, Byul. \# 11.

11. Shidlovskiy, M.S., Zahovayko, O.P. and Diman, M.M. (2017), Porivnyalni pokazniki nadiynosti sistem osteosintezu, Biomedichna Inzheneriya, no. 4, pp. 96-100.

12. Bur'yanov, O.A., Shidlovskiy, M.S., Omelchenko, T.M., Diman, M.M. and Musienko, O.S. (2017), Deformatsiyni harakteristiki sistem fiksatsiyi, scho zastosovuyutsya pri perelomah ta korektsIynih osteotomiyah distalnogo vIddIlu velikogomilkovoyi kistki, Litopis travmatologiyi ta ortopediyi, no. 1-2(35-36), pp. 129-133, http://nbuv.gov.ua/UJRN/Lto 2017 1-2 29

13. Diman, M.M. (2018), Doslidzhennya biomehanichnih harakteristik zasobiv fiksatsiyi perelomIv kistok kintsivok, V kn.: Materiali mizhnarodnoyi naukovo - tehnichnoyi konferentsiyi "Progresivna tehnika, tehnologiya ta inzhenerna osvita", 19-22 chervnya, Kyiv, Ukraina, pp. 48-51.

14. Shidlovskiy, M.S., Diman, M.M. and Omelchenko, T.M. (2017), Deformatsiyni harakteristiki sistem flksatsiyi perelomiv velikogomilkovih kistok, V kn.: Materiali HVIII mizhnarodnoyi naukovo - tehnichnoyi konferentsiyi "Progresivna tehnika, tehnologiya ta inzhenerna osvita", 29 chervnya, 1 lipnya, Kyiv, Ukraina, pp. 64-66. 